\title{
DANA DESA DAN ALOKASI DANA DESA TERHADAP PEMBERDAYAAN EKONOMI MASYARAKAT DI DESA ADODO FORDATAKECAMATAN FORDATA
}

\author{
KABUPATEN KEPULAUAN TANIMBAR
}

\author{
Mihel Tuatfaru \\ Dosen Sekolah Tinggi Ilmu Ekonomi Saumlaki, miheltuatfaru15@gmail.com
}

\begin{abstract}
Abstrak
Untuk mengetahui Pengaruh Presepsi Masyarakat dan Efektifitas Penyaluran Bantuan terhadap Program Pemberdayaan Di Desa Adodo Fordata Kecamatan Fordata Kabupaten Kepulauan Tanimbar.

Tujuan penelitian adalah menganalisis pengaruh Masyarakat dan Efektifitas Penyaluran Bantuan secara parsial maupun simultan terhadap terhadap Program Pemberdayaan Di Desa Adodo Fordata Kecamatan Fordata Kabupaten Kepulauan Tanimbar. Pendekatan penelitian ini adalah secara kuantitatif yang menjelaskan hubungan kausal antara variabel-variabel penelitian melalui pengujian hipotesis. Teknik analisis data yang digunakan adalah analisis regresi berganda, uji asumsi klasik, uji statistik, return to scale dan menggunakan koefisien determinasi $\left(\mathrm{R}^{2}\right)$.

Persamaan Regresi Linier Berganda yang didapat melalui hasil olah data adalah $\mathrm{Y}=7,985+0,252 \mathrm{X}_{1}+0,403 \mathrm{X}_{2}$, Uji Normalitas dalam penelitian hasilnya adalah menunjukan level signifikansi lebih besar dari $\alpha(\alpha=0.05)$ yaitu $0,863>0,05$ yang berarti bahwa data berdistribusi normal.

Hasil Penelitian secara simultan menunjukan bahwa Berdasakan Nilai $\mathrm{F}$ Hitung dan $\mathrm{F}$ Tabel 5,021 > 2,76 dimana $\mathrm{F}$ Hitung $>\mathrm{F}$ Tabel maka variabel variabel Presepsi Masyarakat dan variable Efektifitas Penyaluran Bantuan sangat berpengaruh positif dan signifikan terhadap Program Pemberdayaan masyarakat di Desa Adodo Fordata.

Secara Parsial hasil Penelitian yang diperoleh adalah variabel Presepsi Masyarakat tidak berpengaruh positif secara signifikan terhadap variabel Tingkat Produksi sebab berdasarkan hasil output SPSS adalah 0,026>0,005, sedangkan untuk variabel Efektifitas Penyaluran Bantuan juga tidak berpengaruh positif terhadap Program Pemberdayaan Masyarakat sebab berdasarkan hasil output SPSS adalah 1,689 < 2,064.

Kata Kunci : Dana Desa, Alokasi Dana Desa dan Pemberdayaan Masyarakat
\end{abstract}




\section{Pendahuluan}

Desa, berdasarkan Undang-Undang No. 23 tahun 2014 tentang Pemerintahan Daerah adalah kesatuan masyarakat hukum yang memiliki batas-batas wilayah yuridiksi, yang berwenang untuk mengatur dan mengurus kepentingan masyarakat setempat berdasarkan asal-usul dan adat istiadat setempat yang diakui dan/atau dibentuk dalam sistem Pemerintahan Nasional dan berada di kabupaten/kota, sebagaimana dimaksud dalam UndangUndang Dasar Negara Republik Indonesia Tahun 1945. Landasan pemikiran dalam pengaturan mengenai desa adalah keanekaragaman, partisipasi, otonomi asli, Demokratisasi dan pemberdayaan masyarakat. Proses otonomisasi yang telah digalakkan sejak tahun 1999 hingga saat ini, yang menyangkut berbagai aspek penyelenggaraan pemerintahan dan pembangunan, seharusnya berujung dan berlabuh di desa-desa. Artinya, harus terlihat dengan jelas adanya peningkatan pembangunan dan kesejahteraan desa dan masyarakatnya secara signifikan.

Pembiayaan atau keuangan merupakan faktor vital dalam mendukung penyelenggaraan otonomi desa, sebagaimana juga pada pelaksanaan otonomi daerah.Untuk mengatur rumah tangganya sendiri, desa memerlukan dana/biaya yang memadai untuk melaksanakan semua kewenangan yang dimilikinya. Sejak tahun 1999, yaitu sejak penerapan Undang-Undang Nomor 22 tahun 1999 yang dilanjutkan dengan Undang-Undang nomor 32 tahun 2004 tentang Pemerintahan Daerah, hingga ditetapkannya Undang-Undang 23 Tahun 2014 tentang Pemerintahan Daerahmerupakan paket peraturan perundang-undangan yang esensialnya ditetapkan secara strategis demi keberpihakan kepada masyarakat local di daerah. Menerapkan kebijakan pemberian dana segar (grant) ke desa-desa melalui program kebijakan Alokasi Dana Desa (ADD).

Kabupaten Kepulauan Tanimbar sebagai salah satu kabupaten di Provinsi Maluku, terdiri dari 10 kecamatan, 82 desa dan 2 kelurahan, responsif terhadap tuntutan desa. Kabupaten Kepulauan Tanimbar telah mengalokasikan dana untuk desa sejak tahun 2009 dengan harapan pembangunan semakin merata sampai ke tingkat desa. Namun demikian, minimnya 
jumlah anggaran yang disalurkan menjadi salah satu kendala utama tidak signifikannya pencapaian tujuan mulia dari alokasi dana desa tersebut, khususnya terkait dengan tingkat kesejahteraan masyarakat desa.

Dengan disahkannya Undang-Undang Nomor 6 Tahun 2014 tentang Desa, desa diberikan kesempatan yang besar untuk mengurus tata pemerintahannya sendiri serta pelaksanaan pembangunan untuk meningkatkan kesejahteraan dan kualitas hidup masyarakat desa. Begitu besar peran yang diterima oleh desa, tentunya disertai dengan tanggungjawab yang besar pula. Oleh karena itu pemerintah desa harus bisa menerapkan prinsip akuntabilitas dalam tata pemerintahannya, dimana semua akhir kegiatan penyelenggaran pemerintahan desa harus dapat dipertanggungjawabkan kepada masyarakat desa sesuai dengan ketentuan. Upaya diatas kemudian ditetapkan secara tersruktur melalui paket regulasi teknis demi dipedomani dan dilaksanakan oleh setiap pemerintahan di desa, antara lain Peraturan Pemerintah Nomor 47 Tahun 2015 tentang Perubahan atas Peraturan Pemerintah Nomor 43 Tahun 2014 tentang Peraturan Pelaksanaan Undang-Undang Nomor 6 Tahun 2014 tentang Desa, Peraturan Pemerintah Nomor 08 Tahun 2016 tentang Perubahan Kedua atas Peraturan Pemerintah Nomor 60 Tahun 2014 tentang Dana Desa yang bersumber dari Anggaran Pendapatan dan Belanja Negara, Peraturan Pemerintah Nomor 257 / PMK.07 / 2015 tentang Tata Cara Penundaan dan / atau Pemotongan Dana Perimbangan terhadap Daerah yang tidak memenuhi Alokasi Dana Desa, Peraturan Menteri Keuangan Nomor 49 / PMK.07 / 2016 tentang Tata Cara Pengalokasian, Penyaluran, Penggunaan, Pemantauan dan Evaluasi Dana Desa.

\section{Kajian Teori}

Pengertian umum Desa adalah pengertian yang banyak digunakan oleh masyarakat pada umumnya tentang hakekat atau tentang definisi dari obyek tertentu yang dibahas.Pada umumnya, desa dimaknai oleh masyarakat sebagai tempat bermukim suatu golongan penduduk yang ditandai dengan penggunaan tata bahasa dengan logat kedaerahan yang kental, tingkat pendidikan relatif rendah, dan umumnya warga masyarakatnya bermata pencaharian di bidang agraris atau kelautan. Dalam 
Kamus Umum Bahasa Indonesia disebutkan Desa adalah :

1. wilayah yang dihuni oleh sejumlah keluarga yang mempunyai sistem pemerintahan sendiri (dikepalai oleh Kepala Desa),

2. sekelompok rumah diluar kota yang merupakan kesatuan kampong, dusun,

3. udik atau dusun (dalam arti daerah pedalaman ataulawan dari kota),

4. tempat, tanah, daerah.

Desa berdasarkan ketentuan Pasal 1 angka 1 Undang-Undang Nomor 6 Tahun 2014 tentang Desa didefinisikan sebagai desa dan desa adat atau yang disebut dengan nama lain, selanjutnya disebut desa, adalah kesatuan masyarakat hukum yang memiliki batas wilayah yang berwenang untuk mengatur dan mengurus urusan pemerintahan, kepentingan masyarakat setempat berdasarkan prakarsa masyarakat, hak asal usul, dan/atau hak tradisional yang diakui dan dihormati dalam sistem pemerintahan Negara Kesatuan Republik Indonesia dst.

Menurut Soetardjo Kartohadikoesoemo, desa adalah suatu kesatuan hukum dimana bermukim suatu masyarakat yang berkuasa dan masyarakat tersebut mengadakan pemerintah sendiri.
Sedangkan definisi desa menurut Talizihudu Ndraha dalam bukunya Dimensi-Dimensi Pemerintahan Desa, adalah kesatuan organisasi pemerintahan yang terendah, mempunyai batas wilayah tertentu, langsung dibawah kecamatan, dan merupakan kesatuan masyarakat hukum yang berhak menyelenggarakan rumah tangganya.

Pengertian persepsi dari kamus psikologi adalah berasal dari bahasa Inggris, perception yang artinya: persepsi, penglihatan, tanggapan; adalah proses seseorang menjadi sadar akan segala sesuatu dalam lingkungannya melalui indera-indera yang dimilikinya; atau pengetahuan lingkungan yang diperoleh melalui interpretasi data indera (Kartono dan Gulo, 1987 dalam Adrianto, 2006), Persepsi merupakan suatu proses yang didahului oleh penginderaan. Penginderaan adalah merupakan suatu proses diterimanya stimulus oleh individu melalui alat penerima yaitu alat indera. Pada umumnya stimulus tersebut diteruskan oleh saraf ke otak melalui pusat susunan saraf dan proses selanjutnya merupakan proses persepsi. Stimulus diterima oleh alat indera, kemudian melalui proses persepsi sesuatu yang di indera tersebut menjadi 
sesuatu yang berarti setelah diorganisasaikan dan diinterpretasikan (Davidoff, 1980 dalam Adrianto, 2006).

Melalui persepsi individu dapat menyadari, dapat mengerti tentang keadaan diri individu yang bersangkutan. Persepsi itu merupakan aktivitas yang integrateed, maka seluruh apa yang ada dalam diri individu seperti perasaan, pengalaman, kemampuan berpikir, kerangka acauan dan aspek-aspek lain yang ada dalam diriindividu masyarakat akan ikut berperan dalam persepsi tersebut (Walgito, 2000 dalam Adrianto, 2006). Berdasarkan atas hal tersebut, dapat dikemukakan bahwadalam persepsi itu sekalipun stimulusnya sama tetapi karena pengalaman tidaksama, kemampuan berpikir tidak sama, kerangka acuan tidak sama, adanyakemungkinan hasil persepsi antara individu dengan individu yang lain tidak sama.

Faktor-faktor yang berpengaruh pada persepsi adalah faktor internal: perasaan, pengalaman, kemampuan berpikir, motivasi dan kerangka acuan. Sedangkan faktor eksternal adalah: stimulus itu sendiri dan keadaan lingkungan dimana persepsi itu berlangsung. Kejelasan stimulus akan banyak berpengaruh pada persepsi. Bila stimulus itu berwujud benda-benda bukan manusia, maka ketepatan persepsi lebih terletak pada individu yang mengadakan persepsi karena benda-benda yang dipersepsi tersebut tidak ada usaha untuk mempengaruhi yang mempersepsi.

Pemberdayaan sebagai proses mengembangkan, memandirikan, menswadayakan, memperkuat posisi tawar menawar masyarakat lapisan bawah terhadap kekuatan-kekuatan penekan di segala bidang dan sektor kehidupan (Sutoro Eko, 2002 dalam Cholisin, 2011). Konsep pemberdayaan (masyarakat desa) dapat dipahami juga dengan dua cara pandang. Pertama, pemberdayaan dimaknai dalam konteks menempatkan posisi berdiri masyarakat.Posisi masyarakat bukanlah obyek penerima manfaat (beneficiaries) yang tergantung pada pemberian dari pihak luar seperti pemerintah, melainkan dalam posisi sebagai subyek (agen atau partisipan yang bertindak) yang berbuat secara mandiri.Berbuat secara mandiri bukan berarti lepas dari tanggungjawab Negara.Pemberian layanan publik (kesehatan,pendidikan, perumahan, transportasi dan seterusnya) kepada masyarakat tentu merupakan tugas 
(kewajiban) Negara secara given. Masyarakat yang mandiri sebagai partisipan berarti terbukanya ruang dan kapasitas mengembangkan potensi-kreasi, mengontrol lingkungan dan sumberdayanya sendiri, menyelesaikan masalah secara mandiri, dan ikut menentukan proses politik di ranah negara. Masyarakat ikut berpartisipasi dalam proses pembangunan dan pemerintahan (Sutoro Eko, 2002dalam Cholisin, 2011).

\section{Metode Penelitian}

\section{Lokasi dan Sampel}

Adapun Lokasi Penelitian dalam penelitian ini adalah betempat di Desa Adodo Fordata Kecamatan Fordata Kabupaten Kepulauan Tanimbar

Yang menjadi Sampel dalam penelitian ini adalah Penerima bantuan pada Nelayan di Desa Adodo Fordata.

\section{Teknik Pengumpulan Data}

Adapun teknik pengumpulan data dalam Proposal Penelitian ini adalah.

\section{Observasi}

Observasi dilakukan dengan secara pengambilan data langsung pada Kantor Desa Olilit Raya

\section{Wawancara}

Wawancara dilakukan dengan cara bertatap muka langsung dengan $\mathrm{Pj}$. Kepala Desa dan Aparat Desa serta melibatkan pelaku penerima bantuan.

3. Telaah Dokumen

Dokumen ini diambil dengan cara pengumpulan data awal dan mencari gambaran umum yang berhubungan dengan masalah yang di teliti.

4. Penyebaran Angket

Penyebaran Angket dalam penelitian ini dilakukan dengan cara Observasi, Wawancaradan Data permulaan yang telah dikumpulkan oleh peneliti.

\section{Identifikasi dan Pengukuran Variabel}

1. Identifikasi

Identifikasi masalah dalam penelitian ini adalah memberikan gambaran secara kompleks mengenai data dan informasi terhadap masalah yang diteliti.

2. Pengukuran Variabel

PengukuranVariabel dilakukan dengan cara pengambilan sampel dan populasi serta data-data lain yang mendukung penelitian.

\section{Teknik Analisa Data}

Metode analisis data yang digunakan yaitu analisis regresi sederhana. Analisis ini 
digunakan untuk mengetahui besarnya pengauh Variabel Independent terhadap Variabel Dependent, dengan asumsi variabel yang lain konstan :

$$
\mathrm{Y}=\mathrm{A}+\mathrm{bx}
$$

Uji normalitas digunakan untuk menguji apakah data yang bersangkutan berdistribusi normal atau tidak. Data dikatakan berdistribusi normal jika nilai Asymp. Sig (2-tailed) $\geq 0,05$ maka data terdistribusi dengan normal, jika nilai Asymp. Sig (2-tailed) <0,05 maka distribusi data tidak normal (AliMuhson, 2012).

Uji linieritas bertujuan untuk mengetahui apakah antara variable bebas dan variable terikat mempunyai hubungan linier atau tidak. Untuk mengetahui hal ini digunakan uji $\mathrm{F}$ pada taraf signifikansi 5\%. Jika nilai Sig $\mathrm{F}<0,05$ maka hubungannya tidak linier, sedangkan jika nilai Sig $F \geq 0,05$ maka hubungannya bersifat linier (Ali Muhson, 2012).

\section{Uji Statistik}

UjiF dilakukan untuk mengetahui apakah semua variabel bebas secara bersamasama (simultan) berpengaruh terhadap variabel terikat. Pengujian ini dilakukan dengan membandingkan nilai $F_{\text {hitung }}$ dengan $F_{\text {tabel }}$.Jika nilai $F_{\text {hitung }}>F_{\text {tabel }}$ maka Hoditolak, artinya variable bebas berpengaruh signifikan terhadap variabel terikat, sedangkan jika nilai $F_{\text {hitung }}<F_{\text {tabel }}$ maka Ho diterima, artinya variabel bebas tidak berpengaruh signifikan terhadap variabel terikat.

Untuk mengetahui Nilai F Hitung penulis menggunakan perhitungan berdasarkan hasil olah data dengan menggunakan Program SPSS 14 dan untuk membenarkan nilai $F$ hitung penulis menggunakan persamaan yang disampaikan oleh Sugiyono, 2010:

$$
\mathrm{F}=\frac{R^{2} n-m-1}{m\left(1-R^{2}\right.}+\frac{n(n-1) x^{2}}{2 !}+\cdots
$$

Nilai F tabel yang digunakan adalah nila F tabel yang terdapat dalam Tabel Titik Presentase Distribusi $\mathrm{F}$ untuk probalita $=$ 0,05, dengan dasar perhitungan dengan menentukan derajat bebas atau degree of freedom (df) atau dikenal dengan df2 dan juga dalam $\mathrm{F}$ tabel disimbolkan dengan N2. Hal ini ditentukan dengan rumus:

$$
\mathrm{df} 1=\mathrm{k}-1
$$

$$
\mathrm{df} 2=\mathrm{n}-\mathrm{k}
$$


- $\mathrm{n}=$ Banyaknya observasi dalam kurun waktu data.

- $\mathrm{k}=$ Banyaknya variabel (bebas dan terikat).

Uji statistik digunakan untuk mengetahui besarnya signifikan sipengaruh variable bebas terhadap variable terikat secara individual (parsial) dengan menganggap variabel lain bersifat konstanta. Jika nilai $T_{\text {hitung }}>T_{\text {tabel }}$ maka Ho ditolak, artinya variable bebas berpengaruh signifikan terhadap variabel terikat, sedangkan jika nilai $\quad T_{\text {hitung }}<T_{\text {tabel }}$ maka Ho diterima,artinya $\mathrm{T}$ variabel bebas tidak berpengaruh signifikan terhadap variabel terikat.

\section{Hasil Dan Pembahasan}

Penelitian yang dilakukan ini tentang : "Pengaruh Persepsi Masyarakat dan Efektifitas Penyaluran Bantuan Desa Terhadap Program Pemberdayaan Masyarakat di Desa Adodo Fordata, Kecamatan Fordata Kabupaten Kepulauan Tanimbar ". yang dilakukan peneliti dengan menngunakan sampel sebanyak 35 responden, dan menggunakan alat bantu berupa program SPSS 17 untuk menghitung secara atatistik dalam menganalisa data penelitian yang dikumpulkan melalui kuesioner dalam bentuk jawaban yang diberikan responden melalui pilihan huruf yang tepat sesuai dengan kondisi yang dialami, sehingga penulis dapat mengambil didapati hasil analisa secara ilmiah sebagai berikut:

1. Berdasarkan hasil analisis regresi linier berganda dapat dilihat bahwa: Apabila Presepsi Masyarakat $\quad\left(\mathrm{X}_{1}\right), \quad$ Variabel Efektifitas Penyaluran Bantuan $\left(\mathrm{X}_{2}\right)$ nilainya adalah 0 , maka Tingkat Variabel Program Pemberdayaan (Y) nilainya adalah Rp. 7,985

2. Dalam uji asumsi klasik dengan menggunakan uji normalitas yang dilakukan penulis terhadap keseluruhan variable berdasarkan hasil olah data dengan menggunakan program SPSS 14 dapat disimpulkan bahwa seluruh variable berdistribusi normal dimana nilai probabilitas keseluruhan variable $>0,005$

3. Dalam uji asumsi klasik dengan menggunakan uji Linieritas dengan menggunakan taraf signifikan sebesar 5\% (0,05) serta dengan melihat nilai pada deviation from 
ISSN : 2656-3363 - VoL.2. NO.1 2020

linearity maka dapat disimpulkan bahwa apabila dilihat dari perbandingan nilai $\mathrm{F}$ dengan taraf signifikan maka hubungan linieritas antara variabel Program pemberdayaan (Y) dengan Variabel Presepsi Masyarakat ( $\mathrm{X}_{1}$ ) terdapat hubungan yang linier secara kuat dimana nilai sig $0,010<0,05$ sedangkan nilai pada deviation from linearity 0,124>0,05.

4. Uji Linieritas Variabel Program Pemberdayaan (Y) dengan Variabel Efektifitas Penyaluran Bantuan $\left(\mathrm{X}_{2}\right)$ Berdasarkan hasil olah data yang diperoleh adalah terjadi hubungan yang tidak linieritas antara variabel Program Pemberdayaan (Y) dengan Variabel Efektifitas Penyaluran Bantuan $\left(\mathrm{X}_{2}\right)$ Yaitu sebesar 0,062 > 0,05

5. Uji heteroskedastisitas yang dilakukan penulis dan hasilnya dapat disimpulkan dalam penelitian ini tidak terjadi hubungan Heteroskedastisitas sebab nilai sig untuk variable presepsi Masyarakat $\left(\mathrm{X}_{1}\right)$ dan variable Efektifitas Penyaluran Bantuan $\left(\mathrm{X}_{2}\right)$ keduaduanya mempunyai nilai sig yang lebih besar dari 0,05 (0,863 >0,05

) untuk variable Presepsi

Masyarakat dan ( 0,977>0,05).

H0 diterima, dan Ha Ditolak sehingga dapat ditarik kesimpulan bahwa masalah Heteroskedastisitas tidak ada.

6. Uji Multikolinieritas yang yang dilakukan penulis dapat disimpulkan sebagai berikut:

- Dilihat dari hasil persilangan antara variable bebas diatas maka nilai $r$ dari hasil persilangan variable bebas $<0,800$ maka multikolinieritas tidak terdeteksi.

- Standar eror dan beta pada variabel bebas yang diteliti untuk seluruh indikator variabel bebas kurang dari 1 $(<1)$ oleh sebab itu multikolinearitas tidak terdeteksi.

7. Secara parsial ( Uji t ) berdasarkan hasil uji kedua variable bebas yaitu variable Presepsi Masyarakat dan variabel Efektifitas Penyaluran Bantuan dimana masing-masing secara sendiri-sendiri tidak 
$\begin{array}{lrr}\text { berpengaruh } & \text { positif } & \text { secara } \\ \text { signifikan } & \text { terhadap } & \text { variabel }\end{array}$

Tingkat Produksi

8. Berdasakan Nilai $F_{\text {Hitung }}$ dan $F$ Tabel untuk variable Presepsi Masyarakat $\left(\mathrm{X}_{1}\right)$ dan variable Efektifitas Penyaluran Bantuan (X2), sangat berpengaruh positif secara signifikan terhadap Program Pemberdayaan masyarakat (Y) Di Desa Adodo Fordata Kecamatan Fordata Kabupaten Kepulauan Tanimbar.

9. Berdasarkan olah data Return To Scale dapat disimpulkan bahwa setiap setiap penambahan 1 persen variabel Presepsi Masyarakat, dan variable Efektifitas Penyaluran Bantuan, akan menambah pula nilai Tingkat Program Pemberdayaan Masyarakat sebesar 0,655\%.

10. Nilai Koefisien Determinasi untuk keseluruhan variable bebas adalah 0,271 ( $27 \%$ ), hal ini berarti variabel bebas dalam hal ini adalah variabel Presepsi Masyarakat $\left(\mathrm{X}_{1}\right)$ dan variable Efektifitas Penyaluran Bantuan (X2), dapat berpengaruh terhadap variabel terikat yaitu Program Pemberdayaan masyarakat
(Y) sebesar $27 \%$ sedangkan sisah $73 \%$ dipengaruhi oleh variabel lain yang tidak diteliti oleh penulis.

\section{Kesimpulan Dan Saran}

Berdasarkan Berdasarkan hasil diatas maka kesimpulan secara menyeluruh mengenai pengaruh tingkat Presepsi Masyarakat $\left(\mathrm{X}_{1}\right)$ dan variable Efektifitas Penyaluran Bantuan (X2) berpengaruf positif dan signifikan terhadap tingkat Program Pemberdayaan Masyarakat Desa Adodo Fordata, Kecamatan Fordata Kabupaten Kepulauan Tanimbar, dengan demikian maka Ho ditolak dan $\mathrm{Ha}$ di terima, hingga hipotesis menyatakan ada pengaruh yang positif dan signifikan antara Presepsi Masyarakat dan Efektifitas Penyaluran Bantuan secara parsial maupun simultan terhadap Program Pemberdayaan Masyarakat di Adodo Fordata Kecamatan Fordata Kabupaten Kepulauan Tanimbar dapat diterima. Semakin besar tingkat Presepsi Masyarakat dan Efektifitas Penyaluran Bantuan, maka semakin meningkat pula Program Pemberdayaan Masyarakat. 


\section{DAFTAR PUSTAKA}

Menurut Soetardjo Kartohadi koesoemo, edisi 2 Penerbit Sumur Bandung 1965

Talizihudu Ndraha dalam bukunya Dimensi-Dimensi Pemerintahan Desa.

Menurut Eddi Handono dalam bukunya Membangun Tanggung Gugat Tentang Tata Pemerintahan Desa.

Nurcholis.Kartono dan Gulo, 1987 dalam Adrianto, 2006.

Davidoff, 1980 dalam Adrianto, 2006.Satu Pengantar; Jakarta
Walgito, 2000 dalam Adrianto, 2006.Pengantar Prsikologi Umum, Yogyakarta.

Sutoro Eko, 2002 dalam Cholisin, 2011. Pemberdayaan Masayarakat Desa APMD,Pres Yogyakarta.

Ali Muhson, 2012, Penelitian dan Strategi, Bandung Angkasa.

Sugiyono, 2010, Metode penelitian kuantitatif, Bandung. 
MIPA Fakultas MIPA,

Universitas Negeri Yogyakarta.

Zakaria dan Rizki Yati. Analisa Sosiologi tentang Anak Putus Sekolah di Desa Merah Mege Kecamatan Atu Lintang Kabupaten Aceh Tengah. Universitas Syiah Kuala. 5 